\title{
Expression of Cytological Variability in Some Miscellaneous
}

\section{Legume Accessions}

\author{
Agbolade J0*1, Olakunle $\mathrm{TP}^{2}$, Popoola $\mathrm{KM}^{1}{ }^{1}$, Idowu JA ${ }^{1}$, Isiaka $\mathrm{AI}^{1}$ \\ and Aasa-Sadique $\mathrm{AD}^{3}$ \\ ${ }^{1}$ Department of Plant Science and Biotechnology, Federal University, Nigeria \\ 2Department of Applied Sciences, Osun State Polytechnic, Nigeria \\ ${ }^{3}$ Department of Science Education, Osun State Polytechnic, Nigeria
}

Research Article

Volume 3 Issue 1

Received Date: August 10, 2019

Published Date: September 24, 2019

*Corresponding author: Agbolade J0, Department of Plant Science and Biotechnology, Federal University, Oye Ekiti, Ekiti State, Nigeria, Tel: +2348035741968; Email: oludareagbolade@gmail.com

\begin{abstract}
Variability studies through mitotic and meiotic analyses were considered among twelve (12) species of miscellaneous legumes with two accessions of each species considered. The mitotic and meiotic procedures were carried out following an appropriate relevant literature. Generally, the somatic chromosome counts of $2 n=22$ were very common in the various stages observed, with the meiotic count of $n=11$. The mitotic metaphase chromosome were small in sizes and could be described as being metacentric and sub metacentric, often with one or two pair of satellite chromosomes. Many accessions revealed small chromosomes in most of the species that were not easily distinguished in mitotic cells, most significantly observed in the Vigna spp; Vigna radiata (green gram), Vigna mungo (mung bean) etc. and in Sphenostylis stenocarpa (African yam bean). Although, somatic chromosome counts of $2 n=22$ and meiotic number of $n=11$ are very common among the studied accessions, there is also evidence that chromosome number different from this has been reported for miscellaneous legumes, hence there is an expression of variability in the cytological behaviors of the studied taxa.
\end{abstract}

Keywords: Mitotic; Meiotic; Variability; Chromosome; Accession

\section{Introduction}

Miscellaneous plants are the unpopular species with underutilized potentials; they are also referred to as minor, less, orphan, under cultivated, underutilized and uncommon species [1,2]. The miscellaneous legume species are the unpopular grain legumes which have received insufficient research surveillance unlike the major grain legumes like cowpea and soybean etc. The abandonment has led to the loss or genetic erosion of the germplasm (the genetic source material used by the breeders to develop new cultivars) of many of the minor legumes. Until recently, majority of them are neither cultivated nor found in the wild, they are only maintained or kept as germplasm in some research organizations or institutes for posterity. Majority of the representative 
miscellaneous legumes have not witnessed reasonable research attentions over the year [3].

The use of cytological procedure to resolve evolutionary challenge has been known for ages. Chromosome number, configuration or structure as well as chromosome behavior are particularly of tremendous tool to determine variability among taxa. Data on chromosome number is a "pointer" to the role of numerical disparity while karyotypic statistics assist to apprehend the role of structural changes in the process of evolution [4]. This work was designed to carry out cytological studies through mitotic and meiotic procedures on the twelve species of the miscellaneous legumes with a view to ascertaining their somatic chromosome number and meiotic chromosome behavior. Result obtained serves as useful evaluation data to improve knowledge on their cultivation, utilization and genetic potentials.

\section{Materials and Methods}

The twelve species of the twenty four miscellaneous legumes accessions studied are: Canavalia gladiate (Sword bean-TCg1), Canavalia gladiate (Sword beanTCg4), Pachyrhizus tuberosus (Mexican yam bean-TPtu1), Pachyrhizus tuberosus (Mexican yam bean-TPtu5), Psophocarpus tetragonolobus (Winged bean-TPt12), Psophocarpus tetragonolobus (Winged bean-TPt18), Canavalia ensiformis (Jack bean-TCc1), Canavalia ensiformis (Jack bean-TCc3), Vigna angularis (Rice beanTVa1), Vigna angularis (Rice bean-Va1173), Vigna mungo (Mung bean-TVm12), Vigna mungo (Mung bean-TVm13), Lablab purpureus (Lablab bean-TLn21), Lablab purpureus (Lablab bean-TLn29), Sphenostylis stenocarpa (African yam-TSs137), Sphenostylis stenocarpa (African yam-TSs156), Vigna subterranean (Bambara groundnutTVsu1126), Kerstingiella geocarpa (Kersting groundnutTKg6), Kerstingiella geocarpa (Kersting groundnutTKg12), Vigna radiata (Green gram-TVr45, )Vigna radiate (Green gram-TVr1001), Cajanus cajan (Pigeon peaTCc8127), Cajanus cajan (Pigeon pea-TCc8156).

\section{Mitotic studies}

Root tips were generated from sprouted seeds (obtained from National Centre for Genetic Resources and Biotechnology (NACGRAB) Ibadan, Oyo-state, Nigeria) plated on moistened germination paper in specially made germination plastic. The root tips were pretreated with $0.04 \%$ Colchicine solution when the radicles were about $1 \mathrm{~cm}$ long for three hours between 9am and 12 noon day to keep the majority of the cells at metaphase stage. The root tips were rinsed with tap water and fixed in 1:3 acetic acid /ethanol ( $\mathrm{v} / \mathrm{v}$ ) for twenty four hours before use or kept in the refrigerator. The root tips were further hydrolysed with 1NHCL for 5 minute and then rinsed with tap water. Slides were prepared using squashing method of Olorode [5] as modified by Adegbite and Olorode [6]. A drop of FLP - orcein stain was applied on the squashed root before applying a cover slip on each slide. Each prepared slide was mounted and observed under the microscope to search for dividing cells. Photomicrographs of good mitotic stages were taken at X 1000 magnification under oil immersion.

\section{Meiotic Studies}

Meiotic studies were carried out on pollen mother cells obtained from young flower buds collected between the hours of 9am and 12.00 noon day. The young flower buds were fixed directly in 1:3 acetic acid/ethanol (V/V). The fixed buds were dissected to extract the young anthers. Two of the young anthers were squashed at a time on a clean slide using mounted needle and irrigated with the fixation until homogeneous solution was obtained. A drop of FLP-orcein stain was applied on the slide after which a cover slip was also applied. The slides were observed under the microscope cells. Photomicrographs of good meiotic stages were taken at X1000 magnification under oil immersion.

\section{Results}

Cytology of the various accessions and species of the miscellaneous legumes studies revealed small chromosomes in most of the species that were not easily distinguished in mitotic cells, most significantly observed in the Vigna spp.; Vigna radiata (green gram), Vigna mungo (mung bean) etc. and in Sphenostylis stenocarpa (African yam bean). In the majority, the somatic chromosome counts of $2 n=22$ were very common in the various stages observed, with the meiotic count of $n=11$. The mitotic metaphase chromosome were small in sizes and could be described as being metacentric and submetacentric, often with one or two pair of satellite chromosomes. Chromosome were appeared to be interwoven and coiled at the early prophase stages and could not be counted while there were appearances of chromatin shortening to chromosomes at the late prophase stage. The metaphase chromosomes were clearly distinguishable and were observed to have aligned themselves at the metaphase plate. Figures $1 \& 2$ present the appearance of the various stages observed. 


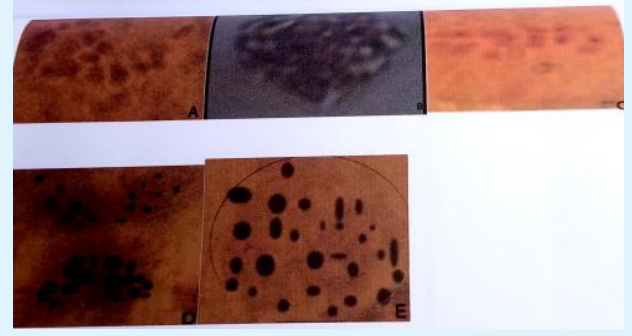

A. Pre-metaphase stage in TSs $137(2 \mathrm{n}=22)$

B. Early Prophase stage in TPt 12

C. Late Metaphase stage in TCg $4(2 n=22)$

D. Anaphase stage in TVm 12

E. Pre-metaphase in TVr 1001

Figure 1: Appearance of mitotic chromosomes in selected miscellaneous legumes studied

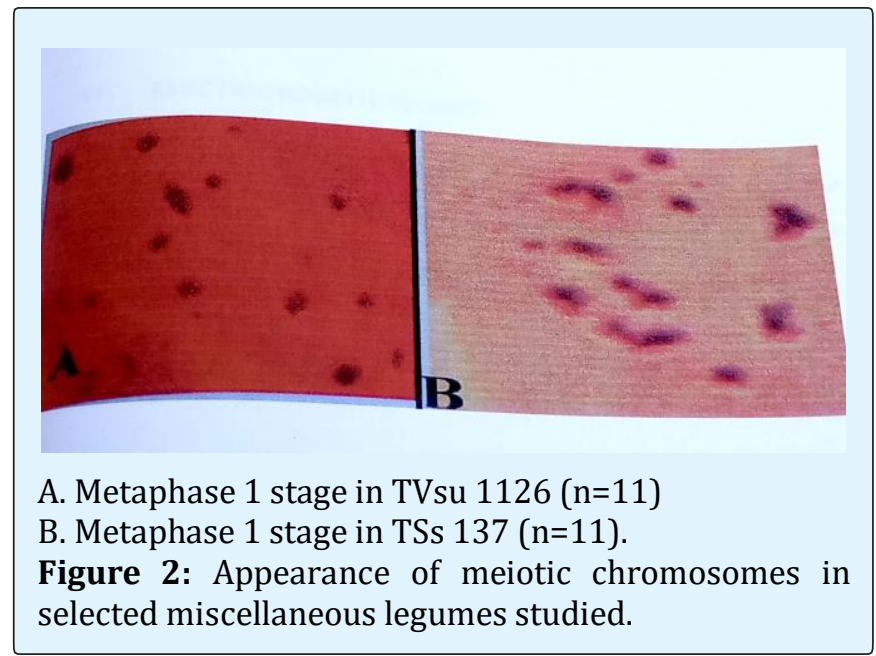

\section{Discussion}

In all the glaringly different species of the miscellaneous legumes, Sphenostylis stenocarpa, Psophocarpus tetregonelobus, canavalia gladiata, Vigna mango and Vigna radiata ( TSs137, Tpt12, TCg4, TVm12 and TVr1001 respectively) considered in this study, a somatic chromosome counts of $2 \mathrm{n}=22$ and meiotic number of $\mathrm{n}=1$ were made in some cells. The chromosomes were small, mostly metacentrics and submetacentrics with one or two pairs of satellite chromosomes. This is similar to previous studies reported for miscellaneous legumes. For example, Peter \& Davidse, 1977 [7] (for the genus Sphenostylis and a sister spieces of Sphenostylis marginata); Munthas, et al. [8] (for Vigna radiata); Brink, et al. [9] (for Vigna subterannea), however, mitoitic chromosome counts of $2 \mathrm{n}=20$ and $2 \mathrm{n}=18$ were also observed in previous studies for Kerstingiella-geocarpa Dako \& Vodouhe [10] and Psophocarpus tetragonolobus Grubben [11] respectively.

\section{Conclusion}

The different species of the miscellaneous legumes considered in this study had somatic chromosome counts of $2 n=22$ and meiotic number of $n=11$. This further lends credence to their genetic relatedness. However, mitotic/somatic chromosome count different from this has also been reported for miscellaneous legumes (Dako and Vodouhe, 2006). We conclude that there is expression of variability in the cytological characters of the studied taxa.

\section{References}

1. Agbolade JO, Komolafe RJ (2016) Genetic diversity and phylogenetic behaviour of some minor legumes. Inter J Plant Biol 7(1): 15-21.

2. Agbolade JO, Popoola JO, Kioko JI, Adewale BD, Ajiboye AA, et al. (2019) Comparative genetic variability and traits heritability in vegetative and floral characters in accessions of two minor legumes. Indian J Agri Res 53: 178-183.

3. Geeta S, Namrata S (2014) Cytology as an Important Tool for Solving Evolutionary Problems in Angiosperms. Proceedings of National Academy of Sciences, India-Section B: Biological Sciences 84(1): 1-7.

4. Popoola JO, Adegbite AE, Obembe 00, Agbolade JO (2011) Reproductive mechanisms and pollen characterization in some accessions of an underutilized legume: (Sphenostylisstenocarpa Hochst Ex. A. Rich) harms. Int J Biodiversity Conservation 3(6): 185-192.

5. Olorode O (1979) Flowering Plants of Nigeria: An Introduction to the Taxonomy of west African Angiosperms. 1 ${ }^{\text {st }}$ (Edn.), pp: 150-164.

6. Adegbite AE, Olorode $O$ (2002) Meiotic studies on some populations of three species of Aspilia, Thouars (Helianthene-Asteraceae) in Nigeria. Nig J Botany 15: 74-83.

7. Peter G, Davidse (1977) Chromosome Numbers in Legumes. Annals of Missouri Botanical Garden 64(1): 121-128. 
8. Munthas S, Chidambaram AA, Sundara Moorthy P, Ganesh KS (2010) Effects of Arsenic and Mangenese on root growth and cell division in root tip cells of green gram (Vigna radiata L.). Emir J Food Agri 22(4): 285-297.

9. Brink M, Ramolemana GM, Sibuga KP (2006) Vigna subterranea (L) Vedc. In Brink M and Belay G (Eds.), PROTA 1: Cereals and pulses/ cereals et legumes secs. (CD-ROM). PROTA, Wageningen, Netherlands.
10. Dako EG, Vodouch SR (2006) Macrotyloma geocarpum (harms) Marechal \& Baudet In: Brink M \& Belay G (Eds.), PROTA 1: Cereals and pulses/cereals et legumes secs. (CD-Rom) PROTA, Wageningen Netherlands.

11. Grubben GJH (2004) Psophocarpus tetragonolobus (L) DC In: Grubben, G.J.H. 8 Denton OA (Eds.), PROTA 2: Vegetables/Legumes (CD-Rom). PROTA, Wageningen, Nertherlands. 